The Bangladesh Veterinarian (2018) 35(1 \& 2): 25 - 31

\title{
Pregnancy rate and associated factors in dairy cows of Bangladesh
}

\author{
MAN Al-Amin, SM Arman, M Afrose ${ }^{1}$, MM Rahman, J Bhattacharjee and \\ MMU Bhuiyan* \\ Department of Surgery and Obstetrics, Faculty of Veterinary Science, Bangladesh \\ Agricultural University, Mymensingh-2202, Bangladesh
}

\begin{abstract}
The study was undertaken to identity the factors affecting the pregnancy rate in cows of commercial dairy farms in Bangladesh. Pre-tested questionnaires were used for collecting data from 662 mixed breed cows of 22 commercial dairy farms. The overall pregnancy rate was $53.6 \%$. Pregnancy rate was the highest $(62.5 \%)$ in local breed $(\mathrm{P}<0.05)$ followed by pure Friesian $(55.5 \%)$, Local $\times$ Friesian $(53.2 \%)$, Sahiwal $\times$ Friesian $(54.5 \%)$ and Local $\times$ Jersey (50.0\%) breed. The cows between 37 and 72 months old had higher pregnancy rate $(58.9 \%)$ than cows aged 18 to $36(44.4 \%)$ and 73 to 192 months $(51.4 \%)(\mathrm{P}<0.05)$. The cows served in parity 2 to 4 had higher pregnancy rate $(57.3 \%)$ than those of parity zero $(45.0 \%)$, $1(50.0 \%)$ and 5 to $10(46.0 \%)(\mathrm{P}<0.05)$. Cows yielding 1-3 litres and 4-10 litres of daily milk showed higher pregnancy rate of 67.1 and $65.8 \%$, respectively, followed by those yielding 11 to 34 litres $(47.4 \%)(\mathrm{P}<0.05)$. Pregnancy rate was higher $(56.5 \%)$ in cows of BCS 3.5 to 4 than those with BCS 2.5 to $3(48.8 \%)$ and BCS $4.5(50.0 \%)(\mathrm{P}<0.05)$. Cows served 181 to 270 days after calving had higher $(62.7 \%)$ pregnancy rate than those served $\leq 90$ days $(48.4 \%)$, 91 to 180 days $(53.7 \%)$ and 271 to 780 days $(45.5 \%)(\mathrm{P}<0.05)$. Cows receiving $2^{\text {nd }}$ service had higher pregnancy rate $(59.4 \%)$ than at $1^{\text {st }}(53.3 \%), 3^{\text {rd }}(53.8 \%)$ and $4^{\text {th }}$ to $17^{\text {th }}(46.4 \%)$ services $(\mathrm{P}<0.05)$. The cows served in the rainy season had higher pregnancy rate $(65.0 \%)$ than those served in summer $(40.0 \%)$ and winter $(61.2 \%)(\mathrm{P}<0.05)$. In conclusion, the present pregnancy rate in cows can be regarded as satisfactory. However, the factors affecting pregnancy rate negatively in commercial farms should be kept in mind for profitable dairying in Bangladesh. (Bangl. vet. 2018. Vol. 35, No. 1 \& 2, 25 - 31)
\end{abstract}

\section{Introduction}

About $85 \%$ of Bangladesh people are engaged in crop and animal agriculture (Raha, 2000). It generates $13 \%$ of foreign exchange earnings and provides full-time employment to about $20 \%$ of the rural population. Due to increased population, the area of farmland is decreasing. Dairying is an important sector creating selfemployment, which is one of the important tools for income generation in Bangladesh. Improving fertility is a common target for dairy herd owners. For maintaining profitable dairy business, optimum pregnancy rate is crucial (Louca and Legates, 1968; Esslemont and Ellis, 1974). In Bangladesh, low pregnancy rate, high

\footnotetext{
1Department of Anatomy and Histology, Faculty of Veterinary Science, Bangladesh Agricultural University, Mymensingh-2202, Bangladesh

*Corresponding author:- E-mail: mmubhuiyan@bau.edu.bd; mmubhuiyan@gmail.com
}

DOI: https://doi.org/10.3329/bvet.v35i1-2.53384 
number of services per pregnancy, prolonged calving to first service interval, extended period between calving and pregnancy, and poor heat detection have been identified as major constraints in reproduction (Alam and Ghosh, 1988; Shamsuddin et al., 2001). Moreover, breed, parity, body condition score (BCS), season of insemination and milk yield may influence the pregnancy rate in dairy cows. Several studies were conducted on pregnancy rate of cows in smallholdings in Bangladesh (Shikder, 2011; Khatun et al., 2014; Hossain et al., 2015). It is essential to evaluate the pregnancy rate of cows on commercial dairy farms and factors that may influence them. The present study was designed to measure the pregnancy rate and its associated factors in selected commercial dairy farms of Bangladesh.

\section{Materials and Methods}

\section{Study area}

The study was conducted at Karnafuli Upazila of Chittagong, Central Cattle Breeding and Dairy Farm (CCBDF) at Savar Upazila of Dhaka and Phulpur Upazila of Mymensingh district.

\section{Data collection}

Data were collected from 662 cows (280 of CCBDF; 354 of Karnafuli; 28 of Phulpur Upazilas) on breed, age, parity, milk yield, BCS, interval between calving to insemination, number of services given, season of insemination and pregnancy using pre-tested questionnaire. The questionnaire was filled in by interviewing the farmers or by examining farm registers.

\section{Management of cows}

Cows were managed by stall feeding with green grass, straw and concentrate with free access to drinking water. The cows were hand-milked twice daily keeping calves at foot. Routine deworming and vaccination were practised. Oestrus was detected by the farmers from clinical signs. The insemination was performed by skilled technicians using frozen semen of proven bulls. Pregnancy was diagnosed by rectal palpation 60 to 90 days after insemination.

\section{Study approaches and statistical analysis}

Pregnancy rate was measured in pure Friesian, Local, Local $\times$ Friesian, Sahiwal $\times$ Friesian and Local $\times$ Jersey cows with various aged groups (18 to 36,37 to 72,73 to 192 months); parities (0, 1, 2 to 4,5 to 10); daily milk yield (1 to 3,4 to 10,11 to 34 litres); BCS (2.5 to 3, 3.5 to 4, 4.5); service intervals ( $\leq 90,91$ to 180, 181 to 270, 271-780 days); number of services $\left(1^{\text {st }}, 2^{\text {nd }}, 3^{\text {rd }}, 4^{\text {th }}\right.$ to $\left.17^{\text {th }}\right)$ and season (rainy, summer and winter). The data were processed using Microsoft Excel Worksheet and analysed by Duncan's Multiple Range Test using SPSS software version 20. The differences were considered significant when $\mathrm{P}$ was less than 0.05 . 


\section{Results and Discussion}

Out of 662 inseminated cows 355 were pregnant, giving a pregnancy rate of $53.6 \%$. Similar pregnancy rates in cows were reported in smallholdings elsewhere in Bangladesh (Khatun et al., 2014; Hossain et al., 2015). Contrasting to the present finding, lower first service pregnancy rate $(46.2 \%)$ was reported by Shamsuddin et al. (2001) and higher rate $(57.3 \%)$ was reported in char area of Sirajgonj district of Bangladesh (Paul et al., 2011). The pregnancy rates among studies might vary due to different management, skill of AI technicians and environment.

The influences of breed, age, parity, milk yield, BCS, interval between calving and insemination, number of services and season of insemination in cows on pregnancy rate in commercial dairy farms are shown in Table 1 . The pregnancy rate was significantly $(\mathrm{P}<0.05)$ higher in local breed $(62.0 \%)$ than in pure Friesian, Local $\times$ Friesian, Sahiwal $\times$ Friesian and Local $\times$ Jersey breed. Similarly, higher pregnancy rate in indigenous cows than in other groups was reported elsewhere (Japri et al., 1997; Paul et al., 2011). The higher pregnancy rate in local cows may be due to better adaptation to the local environment. In contrast, no difference was observed in pregnancy rate between local and crossbred cows in previous studies in Bangladesh (Shikder, 2011; Khatun et al., 2014; Hossain et al., 2015).

Cows inseminated at 37 to 72 months age had significantly $(\mathrm{P}<0.05)$ higher pregnancy rate $(58.9 \%)$ than at 18 to 36 months and 73 to 192 months. Similarly, lower pregnancy rate in young cows was reported by Khatun et al. (2014). On the contrary, Shikder (2011) observed no difference in pregnancy rate among cows of different age groups. The fertility of cows increased slightly up to 3 to 4 years of age and declined after 4 years of age and markedly declined over 7 years of age (Spalding et al., 1975). The reason for low pregnancy rate in young cows may be that these cows may have suffered more from negative energy balance. Older cows might have more chance to get sub-clinical uterine infection.

The cows in parity 2 to 4 had significantly $(\mathrm{P}<0.05)$ higher pregnancy rate $(57.3 \%)$ than in parity zero, parity 1 and parity 5 to 10. Similarly, Khan et al. (2015) reported higher pregnancy rate in cows at $2^{\text {nd }}$ and $3^{\text {rd }}$ parity than in nulliparous cows. Differences in pregnancy rate with respect to parity were demonstrated by earlier studies (Khatun et al., 2014; Mollah et al., 2015). In contrast, no difference in pregnancy rate in cows were observed elsewhere (Shikder, 2011; Haque et al., 2015). Pregnancy rates in cows in their first three parities were higher than in later parities (Fengxum, 1997). Further, Than Hla et al. (2001) reported an increased pregnancy rate with advancing parity from parity 2 up to 6 , and then a decline in parities 7 and 8 . The differences in pregnancy rates with respect to parities might be due to differences in breeds and environment.

The pregnancy rate in cows yielding 1-3 and 4-10 litres milk daily was significantly $(\mathrm{P}<0.05)$ higher $(67.1$ and 65.8\%, respectively) than in cows yielding 11 to 34 litres $(47.4 \%)$. In contrast, pregnancy rate was higher in cows yielding more milk (Mollah et al., 2015). Shamsuddin et al. (2001) obtained higher pregnancy rates in low yielding 
( $\leq 1.0$ litres) cows than in high yielding (>1 to 16 litres). However, Shikder (2011) and Haque et al. (2015) observed no difference in pregnancy rate among cows with different milk yields. The differences between studies might be due to breeds of cows, feeding and management practices.

The cows served at BCS 3.5 to 4 , had significantly $(\mathrm{P}<0.05)$ higher pregnancy rate $(56.5 \%)$ than cows at BCS 2.5 to 3 and 4.5. Haque et al. (2015) also observed the difference in pregnancy rate among cows of different BCS groups, similar to the observation of Shikder (2011). Providing an adequate balanced diet will help to gain good BCS resulting in satisfactory pregnancy rate. Higher pregnancy rates in cows with good BCS are documented by Shamsuddin et al. (2001) in Bangladesh. Nutrition can change gonadotropin secretion and cows with BCS $<3$ had reduced pituitary responsiveness to GnRH (Nolan et al., 1988).

The pregnancy rate in cows inseminated 181 to 270 days after calving was significantly $(\mathrm{P}<0.05)$ higher $(62.7 \%)$ than at $\leq 90,91-180$ and $271-780$ days. Mollah et al. (2015) also observed the difference in pregnancy rate in cows inseminated at different intervals after calving. On the contrary, Haque et al. (2015) observed no differences. This may be because, 181 days after calving, most had minimum or no suckling. Negative effect of suckling on pregnancy rate has been documented by Shamsuddin et al. (2001), who obtained higher pregnancy rate in cows suckling once or twice daily than in cows suckling several times. Moreover, the pregnancy rate was higher in cows with restricted suckling than in those with continuous suckling (Tegegne et al., 1991). The reason may be that suckling inhibits the tonic GnRH and LH secretion (Stevenson et al., 1997).

Cows receiving $2^{\text {nd }}$ service had significantly $(\mathrm{P}<0.05)$ higher pregnancy rate $(59.4 \%)$ than at $1^{\text {st }}, 3^{\text {rd }}$ and $4^{\text {th }}-17^{\text {th }}$ service. Similarly, the pregnancy rate differed significantly among cows of different service groups (Shikder, 2011; Mollah et al., 2015). The $1^{\text {st }}$ service pregnancy rate was $53.3 \%$, which was similar to Balachandran (1975) who recorded an average pregnancy rate of $53.0 \%$ at $1^{\text {st }}$ insemination. On the contrary, Shamsuddin et al. (2001) reported $46.4 \%$ pregnancy rate. The variation in pregnancy rate might be due to different management of cows, semen quality and skill of AI technicians.

The cows served in the rainy season had a significantly $(\mathrm{P}<0.05)$ higher pregnancy rate $(65.0 \%)$ than those served during summer and winter. Similarly, Alam and Ghosh (1988) reported differences in pregnancy rate in different seasons. The differences in pregnancy rate among seasons may be explained by changes in nutrition, environmental temperature and photo period. The pregnancy rate of cows markedly reduced when a higher temperature prevailed for two days before insemination to 4 to 6 days after insemination (Gwazdauskas et al., 1975). Higher temperature and humidity may also affect the pregnancy rate in cows (Zakari et al., 1981). Small ovarian follicles are susceptible to heat stress (Badinga et al., 1993; Wolfenson et al., 1995) and it takes 40 to 50 days for small antral follicles to develop into large dominant follicles (Lussier et al., 1987). The author suggests that the rainy season 
(July-October) may be the best season for good fertility of cows and heifers in Bangladesh when sufficient green grasses are available.

Table 1: Effects of breed, age, parity, milk yield, BCS, interval between calving and insemination, number of services and season of insemination on pregnancy rate of cows

\begin{tabular}{|c|c|c|c|}
\hline Factors & $\begin{array}{l}\text { No. of cows } \\
\text { inseminated }\end{array}$ & No. conceived & $\begin{array}{c}\text { Pregnancy } \\
\text { rate }(\%)\end{array}$ \\
\hline \multicolumn{4}{|l|}{ 1. Breed } \\
\hline Pure Friesian & 9 & 5 & $55.5^{\mathrm{b}}$ \\
\hline Local & 29 & 18 & $62.0^{\mathrm{a}}$ \\
\hline Local $\times$ Friesian & 597 & 318 & $53.2^{\mathrm{bc}}$ \\
\hline Sahiwal $\times$ Friesian & 11 & 6 & $54.5^{\mathrm{b}}$ \\
\hline Local $\times$ Jersey & 16 & 8 & $50.0^{c}$ \\
\hline \multicolumn{4}{|l|}{ 2. Age (months) } \\
\hline $18-36$ & 99 & 44 & $44.4^{\mathrm{c}}$ \\
\hline $37-72$ & 285 & 168 & $58.9^{a}$ \\
\hline 73-192 & 278 & 143 & $51.4^{\mathrm{b}}$ \\
\hline \multicolumn{4}{|l|}{ 3. Parity } \\
\hline 0 & 51 & 23 & $45.0^{c}$ \\
\hline 1 & 140 & 70 & $50.0^{\mathrm{b}}$ \\
\hline $2-4$ & 392 & 225 & $57.3^{a}$ \\
\hline $5-10$ & 79 & 37 & $46.0^{c}$ \\
\hline \multicolumn{4}{|l|}{ 4. Milk yield (litres/day) } \\
\hline $1-3$ & 70 & 47 & $67.1^{\mathrm{a}}$ \\
\hline $4-10$ & 120 & 79 & $65.8^{\mathrm{a}}$ \\
\hline $11-34$ & 278 & 132 & $47.4^{\mathrm{b}}$ \\
\hline \multicolumn{4}{|l|}{ 5. BCS } \\
\hline $2.5-3$ & 225 & 110 & $48.8^{\mathrm{b}}$ \\
\hline $3.5-4$ & 405 & 229 & $56.5^{a}$ \\
\hline 4.5 & 32 & 16 & $50.0^{\mathrm{b}}$ \\
\hline \multicolumn{4}{|c|}{ 6. Interval calving to insemination (days) } \\
\hline$\leq 90$ & 95 & 46 & $48.4^{\mathrm{c}}$ \\
\hline $91-180$ & 175 & 94 & $53.7^{b}$ \\
\hline $181-270$ & 212 & 133 & $62.7^{a}$ \\
\hline $271-780$ & 112 & 51 & $45.5^{c}$ \\
\hline \multicolumn{4}{|l|}{ 7. No. of services } \\
\hline $1^{\text {st }}$ & 236 & 126 & $53.3^{\mathrm{b}}$ \\
\hline $2^{\text {nd }}$ & 180 & 107 & $59.4^{\mathrm{a}}$ \\
\hline $3^{\text {rd }}$ & 104 & 56 & $53.8^{\mathrm{b}}$ \\
\hline $4^{\text {th }}-17^{\text {th }}$ & 142 & 66 & $46.4^{\mathrm{c}}$ \\
\hline \multicolumn{4}{|l|}{ 8. Season } \\
\hline Rainy (July-October) & 143 & 93 & $65.0^{\mathrm{a}}$ \\
\hline Summer (March-June) & 182 & 73 & $40.0^{c}$ \\
\hline Winter (November-February) & 235 & 144 & $61.2^{\mathrm{b}}$ \\
\hline
\end{tabular}

$a, b, c$ Values within the same column with respect to same factor with different superscripts differed significantly $(\mathrm{P}<0.05)$. 


\section{Conclusions}

The overall pregnancy rate in dairy cows of commercial farms was $53.6 \%$ and the highest pregnancy rate was obtained at $2^{\text {nd }}$ service. The highest pregnancy rate was in local non-descriptive cows. Other parameters such as age (37 to 72 months), parity (2 to 4), milk yield (up to 3 litres daily), BCS (3.5 to 4), interval between calving to insemination (181 to 270 days) and the rainy season had good influences on pregnancy rates. It is suggested that good management practices help in achieving the satisfactory pregnancy rate in commercial dairy farms in Bangladesh.

\section{Acknowledgements}

The study was supported by the International Atomic Energy Agency (IAEA), Vienna, Austria (CRP D31028, Contract No: 20654). The Department of Livestock Services and owners of private dairy farms are highly acknowledged for providing data during the study.

\section{References}

Alam MGS, Ghosh A 1988: Reproductive performance in cows: its relation to parity and season. Bangladesh Veterinary Journal 22 51-61.

Badinga L, Thatcher WW, Diaz T, Drost M, Wolfenson D 1993: Effect of environmental heat stress on follicular development and steroidogenesis in lactating Holstein cows. Theriogenology 39 797-810.

Balachandran S 1975: Artificial insemination and herd fertility level of cattle in Sri Lanka. Animal Breeding Abstracts 43375.

Esslemont RJ, Ellis PR 1974: Components of a herd calving interval. The Veterinary Record 95 319-320.

Fengxum Xu 1997: Conception rate of cows and analysis of its correlations. China Dairy Cattle 4 30-31.

Haque MN, Gofur MR, Asaduzzaman KM, Bhuiyan MMU 2015: Factors limiting the pregnancy rates in artificially inseminated cows in Bangladesh. International Journal of Dairy Science 10 278-287.

Hossain MM, Bhuiyan MMU, Rahman MM, Juyena NS 2015: Factors influencing the rates of pregnancy, calving and peri-parturient disorders in heifers at selected char areas of Bangladesh. The Bangladesh Veterinarian 32 65-72.

Japri BM, Majial AM, Fauziah HE, Adrien KP 1997: Effects of breed of sire, percentage of Bos taurus inheritance and season of birth on calving performance of crossbred dairy cattle. Asian-Australasian Journal of Animal Sciences 10 313-317.

Gwazdauskas FC, Wilcox CJ, Thatcher WW 1975: Environmental and managemental factors affecting conception rate in a subtropical climate. Journal of Dairy Scienc $\mathbf{5 8}$ 88-92.

Khan MRK, Uddin J, Gofur MR 2015: Effect of age, parity and breed on conception rate and number of service per conception in artificially inseminated cows. Bangladesh Livestock Journal 1 1-4. 
Khatun MA, Bari FY, Alam MS, Ali MR, Sarkar PK 2014: Post AI conception rate in cattle at Rajarhat, Kurigram, Bangladesh. Wayamba Journal of Animal Science 6 845-854.

Louca A, Legates JE 1968: Production losses in dairy cattle due to days open. Journal of Dairy Science 51 573-583.

Lussier JG, Matton P, Dufour JJ 1987: Growth rates of follicles in the ovary of the cow. Journal of Reproduction and Fertility 81 301-307.

Mollah MFK, Gofur MR, Asaduzzaman KM, Bhuiyan MMU 2015: Conception rate of nondescript Zebu cows and its attributing factors in Bangladesh. Research Journal of Veterinary Sciences 8 42-51.

Nolan CJ, Bull RC, Sasser RG, Ruder CA, Panlasigui PM, Reeves JJ 1988: Postpartum reproduction in protein restricted beef cows: Effect on the hypothalamic-pituitaryovarian axis. Journal of Animal Science 66 3208-3211.

Paul AK, Alam MGS, Shamsuddin M 2011: Factors that limit first service pregnancy rate in cows at char management of Bangladesh. Livestock Research for Rural Development 23 Article \# 57.

Raha SK 2000: Development of livestock sector: issues and evidences. In: Mondal MS Edited Changing Rural Economy of Bangladesh. Bangladesh Economic Association, Eskaton Garden Road, Dhaka.

Shamsuddin M, Bhuiyan MMU, Sikder TK, Sugulle AH, Chanda PK, Alam MGS, Galloway D 2001: Constraints limiting the efficiency of artificial insemination of cattle in Bangladesh. IAEA TECDOC 1220 9-28.

Shikder A 2011: Post AI pregnancy rate of crossbred and zebu cattle using frozen semen at Debhata and Kaligonj Upazilla in Satkhira district. MS in Theriogenology Thesis, Department of Surgery and Obstetrics, Faculty of Veterinary Science, Bangladesh Agricultural University, Mymensingh, Bangladesh.

Spalding RW, Everett RW, Foote RH 1975: Fertility in New York artificially inseminated Holstein herds in dairy herd improvement. Journal of Dairy Science 58 718-723.

Stevenson JS, Lamb GC, Hoffman DJ, Minton JE 1997: Interrelationships of lactation and postpartum anovulation in suckled and milked cows. Livestock Production Science 50 57-74.

Tegegne A, Entwistle KW, Mukasa-Mugerwa E 1992: Effects of supplementary feeding and suckling intensity on postpartum reproductive performance of small East African Zebu cows. Theriogenology 38 97-106.

Than Hla U, Aung Myatt U, Daw Su Su Kyi, Ye Htun Win U 2001: Improvement of cattle production in Myanmar through the use of progesterone RIA to increase efficiency and quality of artificial insemination services. IAEA-TECDOC 1220 45-50.

Wolfenson D, Thatcher WW, Badinga L, Savio JD, Meidan R, Lew BJ, Braw-Tal R, Berman A 1995: Effect of heat stress on follicular development during the estrous cycle in lactating dairy cattle. Biology of Reproduction 52 1106-1113.

Zakari AY, Molokwu ECI, Osori DIK 1981: Effect of season on the oestrous cycle of cows (Bos indicus) indigenous to Northern Nigeria. The Veterinary Record 109 213-215. 